\title{
Optimization of protocol for biodiesel production of linseed (Linum usitatissimum L.) oil
}

\author{
Faizan Ullah', Asghari Bano ${ }^{1}$, Saqib Ali $^{2}$ \\ ${ }^{1}$ Department of Plant Sciences, Quaid-i-Azam University, Islamabad, Pakistan \\ ${ }^{2}$ Department of Chemistry, Quaid-i-Azam University, Islamabad, Pakistan \\ *Corresponding author: banoasghari@gmail.com
}

\begin{abstract}
Attempts were made to optimize variables affecting the yield of linseed oil biodiesel in a base catalyzed transesterification reaction. The variables studied were reaction temperature $\left(40-70^{\circ} \mathrm{C}\right)$, catalyst $(\mathrm{NaOH})$ concentration (0.1-1.5\%) and reaction time (30-180 $\mathrm{min})$. The conversion of linseed oil into methyl esters was confirmed through analytical methods like ${ }^{1} \mathrm{H}$ NMR, gas chromatography (GC) and refractometer. The maximum biodiesel yield $(97 \pm 1.045 \% \mathrm{w} / \mathrm{w})$ was obtained at $0.5 \%$ catalyst concentration, $65^{\circ} \mathrm{C}$ temperature, 180 min reaction time and 6:1 molar ratio of methanol to oil. ${ }^{1} \mathrm{H}$ NMR confirmed the practically obtained $\%$ conversion of triglycerides into methyl esters which was further evidenced by refractometer analyses. The refractive index of biodiesel samples was lower than pure linseed oil. GC analysis confirmed the presence of linolenic acid (C18:3) as the dominant fatty acid (68 wt. \%) followed by oleic acid (C18:1), linoleic acid (C18:2) and stearic acid (C18:0) respectively. The physical properties of linseed oil biodiesel like specific gravity $\left(0.90 \mathrm{~g} / \mathrm{cm}^{3}\right)$ and flash point $\left(177^{\circ} \mathrm{C}\right)$ were higher than American Society for Testing and Materials standards (ASTM 6751) for biodiesel. However, kinematic viscosity $\left(3.752 \mathrm{~mm}^{2} / \mathrm{s}\right)$ was in the range of ASTM standards.
\end{abstract}

Keywords: linseed, biodiesel, protocol, optimization.

\section{INTRODUCTION}

The optimization of biodiesel production from vegetable oil is a several-step process, and is greatly dependant on oil quality of a particular plant species. Previous studies showed that catalyst concentration, temperature and methanol/oil molar ratio are important variables that impact the quality and biodiesel yield in transesterification ${ }^{1}$. The stoichemistry of transesterfication reaction involves $3 \mathrm{~mol}$ of methanol/mol of triglyceride ensuing in $3 \mathrm{~mol}$ of ester and single mol of the glycerol. Therefore, the degree of transesterification and other associated side reactions are dependent on the type of feedstock, catalyst concentration, alcohol/oil molar ratio and temperature of the reaction ${ }^{2}$.

Linseed (Linum usitatissimum L.) belonging to Linaceae is an annual dicotylednous crop, which is cultivated in Pakistan either for seed oil or fiber. Linseed oil is considered as drying oil and frequently used in varnishes and paints. Although linseed oil is edible, its utilization is very limited due to its strong odor and flavor.

The aim of the current investigation was to determine the optimum conditions for the production of linseed oil fatty acid methyl esters via base $(\mathrm{NaOH})$ catalyzed transesterification, and its confirmation by analytical techniques like ${ }^{1} \mathrm{H}$ NMR, GC and refractometer.

\section{EXPERIMENTAL}

Certified seeds of linseed (Linum usitatissimum L.) cv. Chandni, obtained from National Agriculture Research Centre Islamabad, Pakistan, were dried by incubating the seeds overnight in an oven at $30^{\circ} \mathrm{C}$. The oil was extracted in petroleum ether using a soxhlet apparatus. The oil acid value ( $\mathrm{mg}$ of $\mathrm{KOH} / \mathrm{g}$ of oil), free fatty acid content (as oleic acid \%), saponification number (mg of $\mathrm{KOH} / \mathrm{g}$ of oil) and iodine number (g I/100 of oil) was determined according to $\mathrm{AOAC}^{3}$. Specific gravity $\left(\mathrm{g} / \mathrm{cm}^{3}\right)$ was determined using a density bottle according to Pearson ${ }^{4}$. Oil $\mathrm{pH}$ was determined by placing $2 \mathrm{gm}$ of the oil sample into a clean dry $25 \mathrm{~mL}$ beaker. $25 \mathrm{~mL}$ of hot distilled water was added to the sample in the beaker and stirred slowly for a few min. The stirred mixture was cooled to $25^{\circ} \mathrm{C}$ in a water bath. The $\mathrm{pH}$ electrode was standardized with buffer solution, immersed into the sample and the $\mathrm{pH}$ value was recorded ${ }^{5}$.

For biodiesel production, the crude oil was subjected to base catalyzed transesterification. The pellets of sodium hydroxide at $0.1 \%, 0.3,0.5,1$ and $1.5 \%$ (w/w oil) were dissolved in methanol, mixed with oil and stirred on a magnetic stirrer. The molar ratio of methanol to oil was 6:1. Reaction was conducted at temperatures varying from $40,50,60,65$ and $70^{\circ} \mathrm{C}$. The reaction was proceeded for 30-180 min. After the completion of transesterification reaction, the mixture was placed overnight to separate the biodiesel and glycerin phases. To remove the excess of methanol, catalyst and soap produced during the reaction, biodiesel phase was washed with warm distilled water and subsequently dried by using RFE at $120 \mathrm{rpm}$ for $1 \mathrm{~h}$ at $35^{\circ} \mathrm{C}$. The yield of biodiesel was determined on $\% \mathrm{w} / \mathrm{w}$ conversion of linseed oil to biodiesel ${ }^{6}$.

The protocol optimized for maximum conversion of linseed oil into biodiesel was confirmed by ${ }^{1} \mathrm{H}$ NMR, $\mathrm{GC}$ and refractometer. The ${ }^{1} \mathrm{H}$ NMR analyses were performed on Avan CE $300 \mathrm{MHz}$ spectrometer equipped with $5 \mathrm{~mm}$ BBO probes at $7.05 \mathrm{~T}$.

The equation used to quantify the yield of transesterification was: $\mathrm{C}=100 \times 2 \mathrm{AMe} / 3 \mathrm{ACH}_{2}$

Where $\mathrm{C}=$ percentage conversion of triglycerides to corresponding methyl esters, $\mathrm{AMe}=$ integration value of the methoxy protons of the methyl esters and $\mathrm{ACH}_{2}=$ integration value of $\alpha$-methylene protons

The refractive index of pure oil as well as biodiesel samples was determined by Abbe refractometer.

The linseed oil biodiesel fatty acid composition was determined via a gas chromatograph (Shimadzu QP 5050) equipped with a flame ionizing detector (FID) and a fused 
silica capillary column (MN FFAP (50 m x $0.32 \mathrm{~mm}$ i.d; film thickness $0.25 \mu \mathrm{m}$ ). Helium was utilized as carrier gas. The column temperature was maintained at $110^{\circ} \mathrm{C}$ for $0.5 \mathrm{~min}$, raised to $200^{\circ} \mathrm{C}$ at $10^{\circ} \mathrm{C} / \mathrm{min}$ tills $10 \mathrm{~min}^{7}$.

The physical properties of linseed oil biodiesel were determined as per standard methods described by American Society for Testing Materials ${ }^{8}$. The specific gravity $\left(15^{\circ} \mathrm{C}\right)$ was measured by ASTM D 287. The kinematic viscosity was determined at $40^{\circ} \mathrm{C}$, using a viscometer according to ASTM D 445. The flash point was determined by a Pensky-Martens closed-cup tester using ASTM D 93. Cloud and pour point were determined using ASTM D 2500 and ASTM D 97 respectively.

\section{RESULTS AND DISCUSSION}

The linseed oil used in the experiment possessed an acid value of 1.60 ( $\mathrm{mg}$ of $\mathrm{KOHg} /$ of oil), free fatty acid content $0.80 \%$ (as oleic acid), saponification number 189 ( $\mathrm{mg}$ of $\mathrm{KOH} / \mathrm{g}$ of oil), iodine value173 (g I/100 of oil), specific gravity $0.93\left(\mathrm{~g} / \mathrm{cm}^{3}\right)$ and $\mathrm{pH}$ of 6 .

During the present investigation, it was found that increase in temperature from $40^{\circ} \mathrm{C}$ to $65^{\circ} \mathrm{C}$ enhanced the yield of linseed oil biodiesel. The maximum yield $(97 \%)$ of biodiesel was obtained at $65^{\circ} \mathrm{C}, 0.5 \%$ catalyst concentration $(\mathrm{w} / \mathrm{w})$ and methanol/oil molar ratio of $6: 1$. Increase in temperature beyond $65^{\circ} \mathrm{C}$ i.e. $70^{\circ} \mathrm{C}$, there was a decrease in the content of biodiesel and this decrease was greater at higher concentration $(1.5 \%)$ of catalyst (Table 1). Similar results for the impact of temperature and catalyst concentration on biodiesel yield in base catalyzed transesterification reaction were reported by Nosheen et $\mathrm{al}^{9}$ for mustard oil and Ahmad et al. ${ }^{10}$ for sesame oil. The temperature, alcohol/oil molar ratio and catalyst concentration are considered crucial for

Table 1. Effect of process variables on biodiesel yield of linseed oil. The data represent mean of three replica

\begin{tabular}{|l|c|c|c|}
\hline $\begin{array}{l}\text { Catalyst } \\
\text { concentration } \\
{[\mathrm{NaOH} \% \mathrm{w} / \mathrm{w}]}\end{array}$ & $\begin{array}{c}\text { Methanol/oil } \\
\text { molar ratio }\end{array}$ & $\begin{array}{c}\text { Reaction } \\
\text { temperature } \\
{\left[{ }^{0} \mathrm{C}\right]}\end{array}$ & $\begin{array}{c}\text { Yield of } \\
\text { biodiesel } \\
{[\% \mathrm{w} / \mathrm{w}]}\end{array}$ \\
\hline 0.1 & $6: 1$ & 40 & $23 \pm 1.001$ \\
\hline 0.1 & $6: 1$ & 50 & $29 \pm 1.131$ \\
\hline 0.1 & $6: 1$ & 60 & $49 \pm 1.731$ \\
\hline 0.1 & $6: 1$ & 65 & $58 \pm 2.009$ \\
\hline 0.1 & $6: 1$ & 70 & $57 \pm 1.071$ \\
\hline 0.3 & $6: 1$ & 40 & $62 \pm 2.001$ \\
\hline 0.3 & $6: 1$ & 50 & $72 \pm 2.512$ \\
\hline 0.3 & $6: 1$ & 60 & $81 \pm 1.092$ \\
\hline 0.3 & $6: 1$ & 65 & $96 \pm 1.081$ \\
\hline 0.3 & $6: 1$ & 70 & $94 \pm 1.009$ \\
\hline 0.5 & $6: 1$ & 40 & $65 \pm 2.001$ \\
\hline 0.5 & $6: 1$ & 50 & $69 \pm 2.004$ \\
\hline 0.5 & $6: 1$ & 60 & $89 \pm 2.007$ \\
\hline 0.5 & $6: 1$ & 65 & $97 \pm 1.045$ \\
\hline 0.5 & $6: 1$ & 70 & $91 \pm 1.096$ \\
\hline 1 & $6: 1$ & 40 & $65 \pm 2.009$ \\
\hline 1 & $6: 1$ & 50 & $71 \pm 1.094$ \\
\hline 1 & $6: 1$ & 60 & $89 \pm 1.091$ \\
\hline 1 & $6: 1$ & 65 & $91 \pm 1.053$ \\
\hline 1 & $6: 1$ & 70 & $81 \pm 1.954$ \\
\hline 1.5 & $6: 1$ & 40 & $60 \pm 1.0874$ \\
\hline 1.5 & $6: 1$ & 50 & $63 \pm 2.089$ \\
\hline 1.5 & $6: 1$ & 60 & $74 \pm 2.048$ \\
\hline 1.5 & $6: 1$ & 65 & $80 \pm 1.921$ \\
\hline 1.5 & $6: 1$ & 70 & $74 \pm 1.0983$ \\
\hline & & \\
\hline
\end{tabular}

\pm represents standard error values optimizing the protocol for biodiesel production in an alkali catalyzed transesterification. High temperature accelerates the saponification of triglycerides with a subsequent decrease in biodiesel yield ${ }^{\mathbf{1 1}}$. Therefore, transesterification is favored by temperature close to the boiling point of alcohol ${ }^{12}$. The higher concentration of the basic catalyst causes losses into biodiesel yield because excess catalyst reacts with triglycerides and results into the production of soap ${ }^{13}$.

The maximum $(80 \%)$ oil conversion into biodiesel was obtained after $30 \mathrm{~min}$ of reaction initiation. However, there occurred a gradual increase in the yield of biodiesel by increasing the reaction time, maximum and higher biodiesel yield (97\%) was observed after $180 \mathrm{~min}$ of reaction initiation (Fig. 1). The results established that $65^{\circ} \mathrm{C}$ was optimum temperature to carry on successful transesterification with higher biodiesel yields at 180 min reaction.

The conversion efficiency of triglycerides to corresponding methyl esters at $0.5 \%$ catalyst concentration by using ${ }^{1} \mathrm{H}$ NMR was found to be $97.32 \%$ which confirmed the practically observed yield (97\%) of biodiesel. However, the ${ }^{1} \mathrm{H}$ NMR data $(97.63$ and $96.85 \%)$ did not confirm the actual yield of biodiesel obtained practically (91 and $80 \% \mathrm{w} / \mathrm{w}$ ) at $1 \%$ and $1.5 \%$ catalyst concentration respectively (Table 2). These lower biodiesel yields obtained practically in comparison to the calculated yields via ${ }^{1} \mathrm{H}$ NMR could be ameliorated by increasing the settling time for the product mixture and enhancing separation of glycerine and biodiesel phases through centrifugation ${ }^{14}$.

Refractive index is the relation between speed of light in vacuum and speed of light through the substance ${ }^{15}$. Therefore, the refractive index was also determined for pure linseed oil as well as its respective biodiesel samples for confirmation of the process, conversion of triglycerides into methyl esters. The refractive index was higher $\left(1.471\right.$ at $\left.40^{\circ} \mathrm{C}\right)$ for pure oil. The refractive index was also higher $\left(1.46\right.$ at $\left.40^{\circ} \mathrm{C}\right)$ for biodiesel samples (prepared at 0.1 and $0.3 \%$ catalyst concentration) having

Table 2. Biodiesel yield calculated through ${ }^{1} \mathrm{HNMR}$

\begin{tabular}{|l|c|c|}
\hline Catalyst conc. [\%] & Temperature $\left[{ }^{0} \mathrm{C}\right]$ & Biodiesel yield via ${ }^{1} \mathrm{HNMR}[\%]$ \\
\hline 0.3 & 65 & 92.92 \\
\hline 0.5 & 65 & 97.72 \\
\hline 1.0 & 65 & 97.63 \\
\hline 1.5 & 65 & 96.85 \\
\hline
\end{tabular}

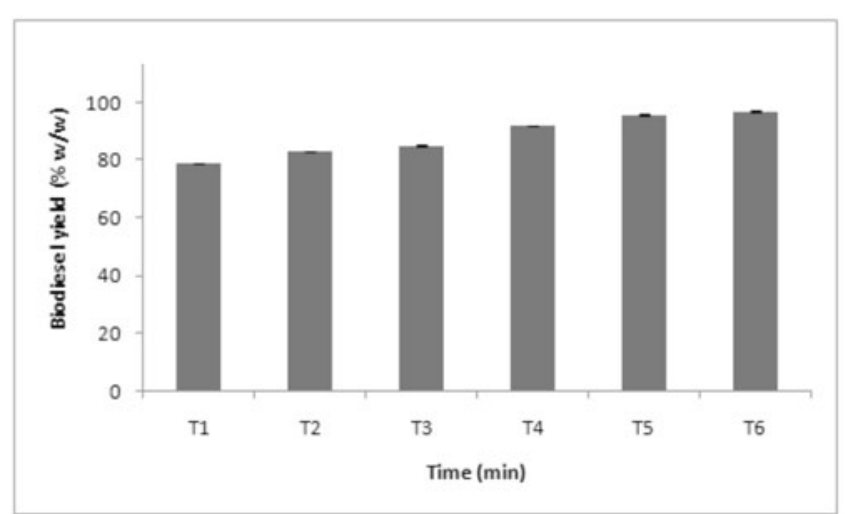

Reaction time: T1-30 min, T2-60 min, T3-90 min, T4-120 min, T5-150 min, T6-180 min

Figure 1. Biodiesel yield at different reaction times (min) for $0.5 \% \mathrm{NaOH}$ concentration, $500 \mathrm{rpm}$ stirring speed and 6:1 molar ratio of methanol to oil 
lower methyl esters content as calculated by ${ }^{1} \mathrm{H}$ NMR analyses. MacLeod ${ }^{\mathbf{1 6}}$ reported that the biodiesel with higher amounts of glycerol exhibited higher refractive index. The biodiesel samples having the maximum methyl esters content (prepared at 0.5 and $1 \%$ catalyst concentration) exhibited lower refractive indices in the range of 1.45 (Fig. 2). These results are in confirmatory with those of Domínguez ${ }^{\mathbf{1 7}}$, who reported that pure biodiesel possesses refractive index in the range of 1.45 . These results are also in agreement with the previous findings of Falate et al. ${ }^{18}$ who reported that biodiesel with higher methyl esters content exhibited lower refractive index. It is therefore inferred that determination of refractive index can be useful for the confirmation of triglycerides conversion into biodiesel.

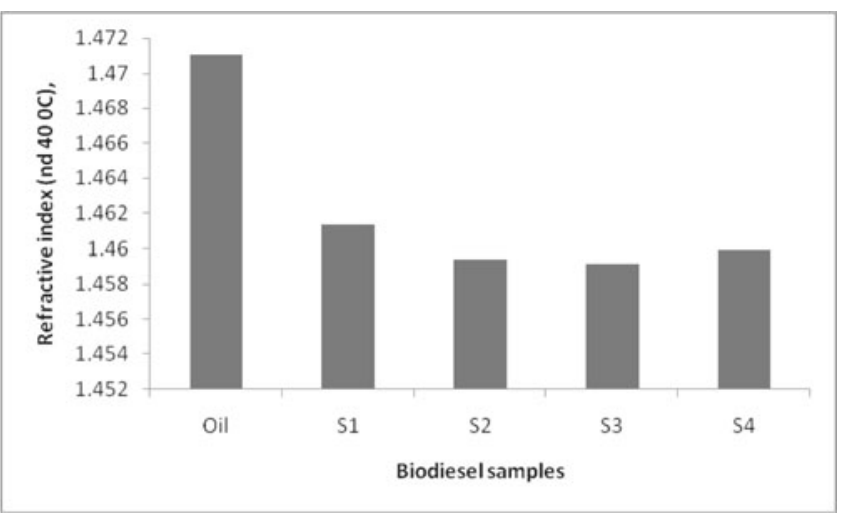

Oil - Pure linseed oil

S1 - Biodiesel sample prepared at $0.3 \%$ catalyst and $65^{\circ} \mathrm{C}$

S2 - Biodiesel sample prepared at $0.5 \%$ catalyst and $65^{\circ} \mathrm{C}$

S3 - Biodiesel sample prepared at $1 \%$ catalyst and $65^{\circ} \mathrm{C}$

$\mathrm{S} 4$ - Biodiesel sample prepared at $1.5 \%$ catalyst and $65^{\circ} \mathrm{C}$

Figure 2. Refractive index of pure linseed oil and its respective biodiesel samples

Figure 3 shows the fatty acid composition of linseed oil biodiesel. Linolenic acid (C18:3) was found as the dominant fatty acid (68 wt \%) followed by oleic acid (C18:1), linoleic acid (C18:2) and stearic acid (C18:0) respectively. It was evident from the results that major portion of linseed oil biodiesel was composed of unsaturated fatty acid methyl esters.

The physical properties of biodiesel like specific gravity $\left(\mathrm{g} / \mathrm{cm}^{3}\right)$, kinematic viscosity $\left(\mathrm{mm}^{2} / \mathrm{s}\right)$, Flash point $\left({ }^{\circ} \mathrm{C}\right)$, Cloud point $\left({ }^{\circ} \mathrm{C}\right)$ and pour point $\left({ }^{\circ} \mathrm{C}\right)$ are given in Table 3 .

The specific gravity of linseed oil biodiesel $\left(0.90 \mathrm{~g} / \mathrm{cm}^{3}\right)$ was higher than ASTM standards for pure biodiesel $\left(0.88 \mathrm{~g} / \mathrm{cm}^{3}\right)$. The flash point is important with perspectives of fuel storage and transportation. It is the

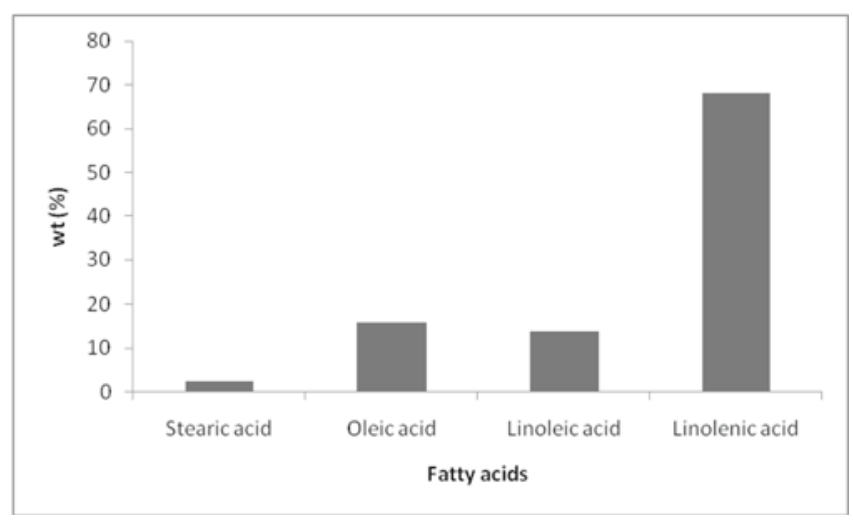

Figure 3. Fatty acid composition of linseed oil biodiesel
Table 3. Physical properties of linseed oil biodiesel

\begin{tabular}{|l|c|c|}
\hline Physical Properties & $\begin{array}{c}\text { Biodiesel from } \\
\text { linseed oil }\end{array}$ & $\begin{array}{c}\text { ASTM } \\
\text { Standards } \\
\text { for Biodiesel }\end{array}$ \\
\hline $\begin{array}{l}\text { Specific gravity }\left[\mathrm{g} / \mathrm{cm}^{3}\right] \\
\text { at } 25^{\circ} \mathrm{C}\end{array}$ & 0.90 & 0.88 \\
\hline $\begin{array}{l}\text { Kinemetic viscosity at } \\
40^{\circ} \mathrm{C}\left[\mathrm{mm}^{2} / \mathrm{s}\right]\end{array}$ & 3.752 & $1.9-6$ \\
\hline Flash Point $\left[{ }^{\circ} \mathrm{C}\right]$ & 177 & 130 \\
\hline Pour Point $\left[{ }^{\circ} \mathrm{C}\right]$ & -7 & - \\
\hline Cloud Point $\left[{ }^{\circ} \mathrm{C}\right]$ & 0 & - \\
\hline
\end{tabular}

temperature at which the fuel gets ignited and catches fire. The flash point of neat biodiesel is always higher than petroleum based diesel ${ }^{19}$. The linseed oil biodiesel possessed a flash point of $177^{\circ} \mathrm{C}$ which seems higher than ASTM 6751 standards $\left(130^{\circ} \mathrm{C}\right)$. The physical and chemical properties of biodiesel depend upon the fatty acid composition of the vegetable oil ${ }^{20}$. The presence of a greater number of unsaturated fatty acids might have contributed to the higher flash point and specific gravity of linseed oil biodiesel. The presence of unsaturated fatty acid esters $(<25 \%)$ having more than two double bonds are associated with higher specific gravity of linseed oil biodiesel $^{21}$. These quality attributes of biodiesel can be improved by making its blends with high speed diesel (HSD) prior to utilization in compression ignition engines $^{22}$. Moreover, improvement in fatty acid composition through breeding ${ }^{23}$ and agrochemicals ${ }^{24}$ may help to improve biodiesel quality of linseed.

The cloud point is the temperature at which the wax crystals appear in fuel and is related to the warmest temperature at which these will form in fuel. Whereas, the pour point is the measure of fuel gelling temperature at which the sampled fuel can no longer be pumped, and this is always lower than the cloud point ${ }^{16}$. The cloud and pour points of linseed oil biodiesel as determined using ASTM D 2500 and ASTM D 97 were 0.00 and $-7^{\circ} \mathrm{C}$ respectively. According to ASTM standard D 6751, there is no specified limit for the cloud point and pour point because the climatic conditions in the world vary considerably, thus greatly affecting the needs of biodiesel users in a specific region'.

\section{ECONOMY OF LINSEED OIL BIODIESEL}

The economic analysis was based on the prices of linseed oil and costs associated with process and production. It was in the range of 1.4 U.S dollar/L. This high cost was mainly due to higher prices of linseed oil in the local market. Linseed is considered as neglected oil seed crop in Pakistan, and cultivated over a small area, even so the climatic condition are much favorable for its cultivation. This cost of production is higher than existing prices of petroleum diesel (0.90 U.S dollar/L) in Pakistan. This cost of production can be reduced by utilizing the byproducts of transesterification reaction like glycerin and soap, linseed stalks for fiber and cake as fodder for cattle. Moreover, the widespread cultivation of this crop throughout the country will further reduce the cost of linseed oil biodiesel on commercial scale. 


\section{CONCLUSION}

It is inferred that $0.5 \% \mathrm{NaOH}, 65^{\circ} \mathrm{C}$ temperature, 180 min reaction time and 6:1 molar ratio of methanol to oil provide an ideal condition for optimizing the linseed oil conversion into methyl esters. ${ }^{1} \mathrm{H}$ NMR and refractometer effectively confirmed the optimized protocol, and can help in future quality control of linseed oil biodiesel on commercial scale.

\section{ACKNOWLEDGMENT}

The authors are highly grateful to Higher Education Commission Pakistan for provision of funds to accomplish this research work under HEC indigenous $\mathrm{PhD}$ fellowship program Pin No. 106-1759-Bm6-017.

\section{LITERATURE CITED}

1. Peterson, C.L., Reece, D.L., Cruz, R. \& Thompson, J. (1992). In: Proceedings of an alternative energy conference of ASAE. 99-110.

2. Anh, N. \& Phan, T.M.P. (2008). Biodiesel production from waste cooking oils. Fuel. 87, 3490-3496. DOI: 10.1016/j. fuel.2008.07.008.

3. AOAC, Official methods of analysis. 15th ed. Association of Official Analytical Chemists, Arlington, VA (1990).

4. Pearson, D. (1976). The Chemical Analysis of Food. Churchill, Livingstone, pp. 488-496.

5. Akubugwo, I.E. \& Ugbogu, A.E. (2007). Physiochemical studies on oils from five selected Nigerian plant seeds. Pak. J. Nut. 6, 75-78.

6. Rashid U. \& Anwar, F. (2008). Production of Biodiesel through Base-Catalyzed Transesterification of Safflower Oil Using an Optimized Protocol. Energy Fuel. 22, 1306-1312. DOI: $10.1021 /$ ef700548s.

7. Camas, N., Cirak, C. \& Esendal, E. (2007). Seed yield, oil content and fatty acids composition of safflower (Carthamus tinctorius L.) grown in northern Turkey conditions. Uni Ondokuz Mayls J. Fac. Agric. 22, 98-104.

8. American Standards for Testing of Materials. (2003). American Society of Agricultural Engineers (ASAE), St. Joseph, MI.

9. Nosheen, A., Bano A. \& Ullah, F. (2012). Optimization of biodiesel production from Yellow sarson (Brassica campestris L.) oil. Energy Sourc. Part A. 35, 278-281. DOI:10.1080/1556 7036.2010.511431.

10. Ahmad, M., Khan, M.A., Zafar, M. \& Sultana, S. (2010). Environment friendly renewable energy from Sesame biodiesel. Energy Sourc. Part A, 32 (2), 189-196. DOI: 10.1080/15567030802467480.

11. Eevera, T., Rajendran, K. \& Saradha, S. (2009). Biodiesel production process optimization and characterization to assess the suitability of the product for varied environmental conditions. Renew. Energy. 34, 762-765. DOI: 10.1016/j.renene.2008.04.006.

12. Ma, F., Clements, L.D. \& Hanna, M.A. (1998). The effects of catalyst, free fatty acids, and water on transesterification of beef tallow. Transact. Am. Soc. Agric. Eng. 41, 1261-1264. American Society of Agricultural Engineers 0001-2351/98/4105-1261.

13. Leung D.Y.C. \& Guo, Y. (2006). Transesterification of neat and used frying oil: optimization for biodiesel production. Fuel Process. Technol. 87, 883-890. DOI: 10.1016/j. fuproc. 2006.06.003.

14. Tariq, M., Ali, S., Ahmad, F., Ahmad, M., Zafar, M., Khalid, N. \& Khan, M.A. (2011). Identification, FT-IR, NMR $\left({ }^{1} \mathrm{H}\right.$ and $\left.{ }^{13} \mathrm{C}\right)$ and $\mathrm{GC} / \mathrm{MS}$ studies of fatty acid methyl esters in biodiesel from rocket seed oil. Fuel Process.Technol. 91, 336-341. DOI: 10.1016/j.fuproc.2010.09.025.
15. Sales, A. (2011). Production of biodiesel from sunflower oil and ethanol by base catalyzed Transesterification. Department of Chemical Engineering Royal Institute of Technology (KTH) Stockholm, Sweden.

16. MacLeod. C. (2008). Evaluation of Heterogeneous Catalysts for Biodiesel Production. School of Chemical Engineering and Advanced Material, Newcastle University.

17. Domínguez, L.Á.A. (1996). Biofuels: use of vegetable oils as renewable energy. Madrid: Ministry of Agriculture, Fisheries and Food. pp. 203, ISBN 84-491-0181-6.

18. Falate, R., Nike, K., da Costa Neto, P.R., Cação Jr, E., Muller, M., Kalinowski, H.J. \& Fabris, J.L. (2007). Alternative technique for biodiesel quality control using an optical fiber long-period grating sensor. Quim. Nova. 30, 1677. DOI: 10.1590/ S0100-40422007000700034.

19. Ali, Y., Hanna, M.A. \& Cuppett, S.L. (1995). Fuel properties of tallow and soybean oil esters. J. Am. Oil Chem. Soc. 72, 1557. DOI: 10.1007/BF02577854.

20. Pinzi, S., Leiva, D., Arzamendi, G., Gandia, L.M. \& Dorado, M.P. (2011). Multiple response optimization of vegetable oils fatty acid composition to improve biodiesel physical properties. Biores. Technol. 102, 7280-7288. DOI: 10.1016/j. biortech.2011.05.005.

21. Sanford, S.D., White, J.M., Shah, P.S., Wee, C., Valverde, M.A. \& Meier G.R. (2009). Feedstock and biodiesel characteristics report; Renewable Energy Group, Inc; www.regfuel.com

22. Bajpai, D. \& Tyagi, V.K. (2006). Biodiesel: Source, Production, Composition, Properties and Its Benefits. J. Oleo Sci. 55 (10), 487-502. DOI: 10.5650/jos.55.487.

23. Najeeb, U., Mirza, M.Y., Jilani, G., Mubashir, A.K. \& Zhou, W.J. (2012). Sesame. In S.K. Gupta (Ed.), Technological Innovations in Major World Oil Crops, Vol 1: Breeding, (pp. 131-145). Springer Science+Business Media, LLC, 233 Spring Street, New York, NY 10013, USA.

24. Ullah, F. \& Bano, A. (2011). Effect of plant growth regulators on oil yield and biodiesel production of safflower (Carthamus tinctorius L.). Braz. J. Plant Physiol. 23, 27-31. DOI: $10.1590 /$ S1677-04202011000100005. 